\title{
Isolation and characterization of arsenite oxidizing Pseudomonas lubricans and its potential use in bioremediation of wastewater
}

\author{
Abdul Rehman*, S. Awais Butt and Shahida Hasnain \\ Department of Microbiology and Molecular Genetics, University of the Punjab, New Campus, Lahore 54590, Pakistan
}

Accepted 6 January, 2010

\begin{abstract}
A bacterium, Pseudomonas lubricans, isolated from heavy metal laden industrial wastewater, has been shown to tolerate multiple heavy metals suggesting its importance in bioremediation of industrial effluents. P. Iubricans tolerated As(III) up to $3 \mathrm{mg} \mathrm{ml}^{-1}, \mathrm{Cu}^{2+}$ up to $0.7 \mathrm{mg} \mathrm{ml}^{-1}, \mathrm{Hg}^{2+}$ up to $0.4 \mathrm{mg} \mathrm{m}^{-1}, \mathrm{Ni}^{2+}$ up to $0.4 \mathrm{mg} \mathrm{ml}^{-1}$ and $\mathrm{Cr}^{6+}$ up to $0.5 \mathrm{mg} \mathrm{ml}^{-1}$. P. lubricans showed optimum growth at $\mathrm{pH} 7$ while optimum temperature for growth was $30^{\circ} \mathrm{C}$. P. Iubricans could oxidize As(III) $42 \%$ (42 $\mu \mathrm{g} \mathrm{mg}^{-1}$ of protein), $78 \%\left(78 \mu \mathrm{g} \mathrm{mg}^{-1}\right.$ of protein) and $95 \%\left(95 \mu \mathrm{g} \mathrm{m}^{-1}\right.$ of protein) from the medium after 24,48 and $72 \mathrm{~h}$ of incubation at optimal conditions, respectively. The arsenite oxidizing ability shown by $P$. lubricans indicates its potential application in biological treatment of wastewaters contaminated with arsenic.
\end{abstract}

Key words: Arsenic, wastewater, Pseudomonas lubricans, bioremediation.

\section{INTRODUCTION}

Arsenic is the most prevalent environmental toxic metal and is first on the superfund list of hazardous substances. Presently, arsenic contamination of drinking water constitutes an important public health problem in numerous countries throughout the world (Smith et al., 2002; Arriaza, 2005; Liu et al., 2009). Arsenic is a known human carcinogen (Hughes, 2002; Shi et al., 2004). Arsenic toxicity causes skin lesions and damage mucous membranes, digestive, respiratory, circulatory and nervous system. Moreover, it is associated with skin, liver and lung cancers (Wang et al., 2001). So, the World Health Organization recommends a provisional drinking water guideline of $10 \mathrm{ppb}$ for arsenic.

Arsenic has been shown to induce chromosomal aberrations and sister chromatid exchanges when present during DNA replication, the results of genotoxicity studies indicated that it is mutagenic. It may interfere with the DNA repair system or DNA methylation state, inhibition of

*Correspondence author. E-mail: rehman_mmg@yahoo.com. Tel: 92-42-99231249.

Abbreviations: LB, Luria-bertani; MIC, minimum inhibitory concentration; DCPIP, dichlorophenolindophenol; PMS, phenazine methosilfate. p53 and telomerase activities (Chou et al., 2001; Wang et al., 2001), oxidative stress, promotion of cell proliferation and signal transduction pathways leading to the activation of transcription factors (Wu et al., 1999). It has also been shown that arsenic induces DNA damage via the production of reactive oxygen species (Matsui et al., 1999).

Conventional methods for removing metals from Industrial effluents include chemical precipitation, oxidation or reduction, ion exchange, filtration, electrochemical treatment, reverse osmosis, membrane technologies and evaporation recovery (Ahluwalia and Goyal, 2007; Kuan et al., 2009; Mouedhen et al., 2009). These processes may be ineffective or extremely expensive especially when the metals in solution are in the range of $1-100 \mathrm{mg}$ $I^{-1}$ (Nourbakhsh et al., 1994). Therefore, it is important to develop an innovative, low cost and eco-friendly technique for metal removal from water.

A large number of microorganisms are capable of growing in the presence of high concentrations of heavy metal (Nies, 1992; Gaballa and Helmann, 2003; Rehman et al., 2007). Anderson and Cook (2004) have reported strains of Aeromonas, Exiguobacterium, Acinetobacter, Bacillus and Pseudomonas, that can tolerate high concentrations of arsenic species (up to $100 \mathrm{mM}$ arsenate or up to $20 \mathrm{mM}$ arsenite). Several bacteria (Cervantes et al., 
1994; Ahmed and Rehman, 2009) belonging to the genera Acidithiobacillus, Bacillus, Deinococcus, Desulfitobacterium and Pseudomonas (de-Vicente et al., 1990; Dopson et al., 2001; Niggemyer et al., 2001; Suresh et al., 2004) have also been reported to be resistant to arsenic. Since heavy metals are ubiquitously present in the environment, microorganisms have developed mechanisms to resist the toxic effects of these metals (White and Gadd, 1986).

The study deals with the isolation and characterization of arsenic resistant bacterium from a contaminated environment able to oxidize arsenite and to assess this property for its exploitation in metal detoxification and environmental bioremediation.

\section{MATERIALS AND METHODS}

\section{Sample collection and analysis}

Industrial wastewater samples were collected in screw capped sterilized bottles from Sheikhupura (Pakistan). Some physicochemical parameters of wastewater namely: temperature, $\mathrm{pH}$, dissolved oxygen and arsenic concentration were measured according to APHA (1989).

\section{Isolation of arsenite resistant bacteria}

For isolation of arsenic resistant bacteria, $100 \mu \mathrm{l}$ of the wastewater sample was spread on Luria-Bertani (LB) agar plates containing $100 \mu \mathrm{g} \mathrm{As}(\mathrm{III}) \mathrm{ml}^{-1}$. LB agar plates were prepared by dissolving $1 \mathrm{~g}$ $\mathrm{NaCl}, 1 \mathrm{~g}$ tryptone and $0.5 \mathrm{~g}$ yeast extract in $100 \mathrm{ml}$ distilled water, $\mathrm{pH}$ adjusted to $7-7.2$ and then $1.5 \mathrm{~g}$ agar was added in 250-ml flask. The medium was autoclaved at $121^{\circ} \mathrm{C}$ for $15 \mathrm{~min}$. The growth of the bacterial colonies was observed after $24 \mathrm{~h}$ of incubation at $30^{\circ} \mathrm{C}$. Effect of As (III) on the growth of bacterial isolate was determined in acetate minimal medium (Pattanapipitpaisal et al., 2001) which contained $(\mathrm{g} / \mathrm{l}): \mathrm{NH}_{4} \mathrm{Cl}, 1.0 ; \mathrm{CaCl}_{2} \mathrm{H}_{2} \mathrm{O}, 0.001 ; \mathrm{MgSO}_{4} .7 \mathrm{H}_{2} \mathrm{O}$, $0.2 ; \mathrm{FeSO}_{4} .7 \mathrm{H}_{2} \mathrm{O}, 0.001$; sodium acetate, 5 ; yeast extract, 0.5 ; $\mathrm{K}_{2} \mathrm{HPO}_{4}, 0.5(\mathrm{pH} 7)$ supplemented with $\mathrm{NaH}_{2} \mathrm{AsO}_{3}\left(100 \mu \mathrm{g} \mathrm{ml} l^{-1}\right)$. It was again incubated at $30^{\circ} \mathrm{C}$ for $24 \mathrm{~h}$. This process was repeated with successively higher arsenite concentrations $(0.1,0.2,0.3$ and 3 $\mathrm{mg} \mathrm{ml}^{-1}$ ) until the minimum inhibitory concentration (MIC) of the bacterial isolate was obtained. Experiments were carried out in duplicate.

For screening the arsenite-oxidizing bacteria, the $\mathrm{AgNO}_{3}$ method described by Simeonova et al. (2004) was used. Agar plates (acetate minimal medium) with $\mathrm{NaH}_{2} \mathrm{AsO}_{3}\left(100 \mu \mathrm{g} \mathrm{ml}^{-1}\right)$ were inoculated with arsenite resistant bacterial isolates, incubated at $30^{\circ} \mathrm{C}$ for $48 \mathrm{~h}$ and flooded with a solution of $0.1 \mathrm{M} \mathrm{AgNO}_{3}$. A brownish precipitate revealed the presence of arsenate in the medium (Lett et al., 2001).

\section{Identification of the bacterial isolate}

For molecular identification, genomic DNA was extracted as described by Carozzi et al. (1991) and the 16S rRNA gene was amplified by PCR using 16S rRNA primers (RS-1; 5'-AAACTCAAATGAATTGACGG-3' and RS-3; 5'-ACGGGCGGTGTGTAC-3') (Rehman et al., 2007). PCR was performed by initial denaturation at $94^{\circ} \mathrm{C}$ for $5 \mathrm{~min}$ followed by 35 cycles of denaturation at $94^{\circ} \mathrm{C}$ for $1 \mathrm{~min}$, annealing at $55^{\circ} \mathrm{C}$ for $1 \mathrm{~min}$, extension at $72^{\circ} \mathrm{C}$ for $2 \mathrm{~min}$ and a final extension at $72^{\circ} \mathrm{C}$ for $5 \mathrm{~min}$. The PCR product of $0.5 \mathrm{~kb}$ was removed from the gel and cloned in $\mathrm{pTZ57R/T}$ vector. The amplified 16S rRNA gene was purified with a fermentas purification kit (\#K0513) and the amplified products were electrophoresed on $1 \%$ agarose gel. Sequencing was carried out by Genetic analysis system model CEQ-800 (Beckman) Coulter Inc. Fullerton, CA, USA. The 16S rRNA gene sequences were compared with known sequences in the GenBank database to identify the most similar sequence alignment.

\section{Determination of optimum growth conditions}

For optimum growth of the bacterium, two parameters that is temperature and $\mathrm{pH}$ were considered. For determination of optimum temperature, $5 \mathrm{ml}$ LB broth was added in 4 sets, each of three test tubes, autoclaved and inoculated with $20 \mu \mathrm{l}$ of freshly prepared culture of bacterial isolate by overnight growth at $37^{\circ} \mathrm{C}$ in LB broth. The four sets of tubes were incubated at $25,30,37$ and $45^{\circ} \mathrm{C}$. After $12 \mathrm{~h}$ incubation period, their absorbance was measured at $600 \mathrm{~nm}$ using a LAMBDA 650 UV/Vis spectrophotometer (PerkinElmer, USA). For determination of optimum $\mathrm{pH}$, test tubes having $5 \mathrm{ml} \mathrm{LB}$ broth were prepared in 9 sets, each containing 3 test tubes and their $\mathrm{pH}$ was adjusted to $6.0,6.5,7.0,7.5,8.0,8.5$ and 9.0 , then autoclaved. These tubes were inoculated with $20 \mu \mathrm{l}$ freshly prepared culture of the bacterium. After an incubation period of $12 \mathrm{~h}$, their absorbance was measured at $600 \mathrm{~nm}$.

\section{Effect of arsenite on bacterial growth}

Growth curves of bacterial isolate were determined in acetate minimal medium with different concentrations of arsenite $0,0.5,1,2$ and $3 \mathrm{mg} \mathrm{ml}^{-1}$. For bacterial isolate $50 \mathrm{ml}$ medium was taken in one set consisting of 5 flasks, autoclaved and then inoculated with $20 \mu \mathrm{l}$ of the freshly prepared inoculums. The cultures were incubated at $30^{\circ} \mathrm{C}$ in an incubator shaker at $100 \mathrm{rpm}$. An aliquot of culture was taken at regular intervals $(0,4,8,12,16,20,24,28,32$ and $36 \mathrm{~h})$ to measure absorbance at $600 \mathrm{~nm}$.

\section{Resistance to heavy metal ions}

The cross heavy metal resistance of bacterial isolate was determined by using stock solutions of $10 \mathrm{mg} \mathrm{ml}^{-1}$ of different metal salts (cadmium chloride, copper sulphate, potassium dichromate, mercuric chloride and nickel chloride). The cross metal resistance was checked by increasing the concentration of respective metal in a stepwise manner with $100 \mu \mathrm{g} \mathrm{ml}^{-1}$ in acetate minimal medium. Culture flasks containing $100 \mathrm{ml}$ medium and metal ions were inoculated with $20 \mu \mathrm{l}$ from overnight bacterial cultures and incubated at $30^{\circ} \mathrm{C}$ for $24 \mathrm{~h}$. Growth was measured as optical density at $600 \mathrm{~nm}$.

\section{Arsenic oxidation by bacterial isolate}

The ability of bacterial isolate to oxidize arsenite was checked by adding As (III) at a concentration of $100 \mu \mathrm{g} \mathrm{ml}^{-1}$ in the acetate minimal medium. The control culture medium was also run for As (III) containing the same concentration as in treated one that is, 100 $\mu \mathrm{g} \mathrm{ml}^{-1}$ but without bacterial isolate. The cultures were incubated at $30^{\circ} \mathrm{C}$ for $24 \mathrm{~h}$ and cells were harvested by centrifugation at 14000 rpm for $10 \mathrm{~min}$, washed twice in $50 \mathrm{mM}$ phosphate buffer $(\mathrm{pH} 7)$ and re-suspended in $5 \mathrm{ml}$ of $50 \mathrm{mM}$ phosphate buffer $(\mathrm{pH} \mathrm{7)}$. Cells were disrupted by sonication (Heilscher Ultrasonic Processors UP $400, \mathrm{~S})$ at $4^{\circ} \mathrm{C}$ for 1 time for $15 \mathrm{~s}$ and centrifuged at $14000 \mathrm{rpm}$ for 1 $\mathrm{h}$ at $4^{\circ} \mathrm{C}$. The pellet re-suspended in $50 \mathrm{mM}$ phosphate buffer $(\mathrm{pH}$ 7) represents the membrane fraction while the supernatant represents the soluble fraction. Arsenite oxidase activity was 


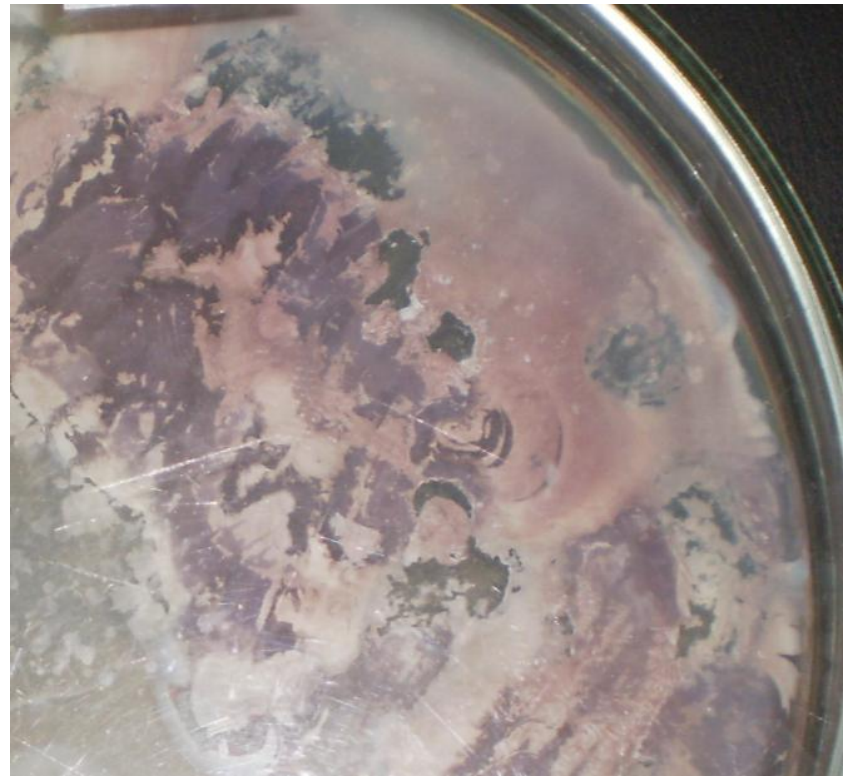

Figure 1. Appearance of brownish precipitate after the application of $0.1 \mathrm{M} \mathrm{AgNO}_{3}$ in agar plate supplemented with $\mathrm{NaH}_{2} \mathrm{AsO}_{3}\left(100 \mu \mathrm{g} \mathrm{ml}^{-1}\right)$ in which $P$. lubricans was growing.

determined by transfer of reducing equivalents from As(III) $200 \mu \mathrm{M}$ 2, 4 -dichlorophenolindophenol (DCPIP) in $50 \mathrm{mM}$ phosphate buffer $(\mathrm{pH} 7)$ with $2 \mathrm{mM}$ phenazine methosilfate (PMS) after suitable time intervals (Anderson et al.,1992). The protein concentration was estimated by the Lowry method (1951) after hydrolysis of the cells in $0.4 \mathrm{~N} \mathrm{NaOH}$ at $100^{\circ} \mathrm{C}$ for $10 \mathrm{~min}$. Bovine serum albumin was used as standard.

\section{Statistical analysis}

Observations were made and all the experiments were run in triplicate. At least three separate flasks were usually maintained for one treatment. Each time three readings were taken, their mean and standard error of the mean were calculated.

\section{RESULTS}

\section{Physicochemical characteristics of wastewater}

Some physicochemical characteristics of industrial wastewater were ascertained, from where arsenic tolerant bacteria were isolated. The temperature of different samples ranged between 28 to $35^{\circ} \mathrm{C}, \mathrm{pH}$ ranged between 6.4 and 8.0, dissolved oxygen between $0.42 \pm 0.03$ and $1.20 \pm$ $0.01 \mathrm{mg} \mathrm{I}^{-1}$ and As ranged between $0.80 \pm 0.04$ and 1.92 $\pm 0.03 \mu \mathrm{g} \mathrm{ml}^{-1}$.

\section{Isolation of arsenic-oxidizing bacterium}

Six bacterial isolates were obtained initially when $100 \mu \mathrm{g}$ As(III) $\mathrm{ml}^{-1}$ in the medium was provided and isolation of single colonies on plates, containing high concentrations of $\mathrm{As}$ (III) on which the organisms were originally isolated. Only one bacterial isolate resisted As(III) up to $3 \mathrm{mg} \mathrm{ml}^{-1}$ and was selected for further study. When tested with $\mathrm{AgNO}_{3}$ in agar plates, only one bacterial isolate demonstrated the ability to oxidize arsenite into arsenate. The silver nitrate test was based on the quality reaction between $\mathrm{AgNO}_{3}$ and arsenite or arsenate ions. The interaction with $\mathrm{As}(\mathrm{III})$ generate bright yellow precipitate and with $\mathrm{As}(\mathrm{V})$ brownish precipitate (Krumova et al., 2008). In this study, Pseudomonas lubricans isolated from Industrial wastewater showed high arsenite oxidizing potential (Figure 1).

\section{Bacterial identification}

The partially amplified (500 bp) fragment of 16S rRNA gene from local isolate was uploaded to the NCBI (National Center for Biotechnology Information) website to search for similarity to known DNA sequences and to confirm the species of this local isolate. The BLAST query revealed that this gene is $98 \%$ homologous to $P$. lubricans. The nucleotide sequences coding for the $16 \mathrm{~S}$ rRNA gene of $P$. lubricans have been submitted to the GenBank database under accession number EU729357. Other close matches included $P$. lubricans strain RS1 DQ842018.3, (gi/225908541); 100\% similarity), Pseudomonas sp. KT-ql-122 FJ611930.1, (gi/ 222431647); 100\% similarity), Pseudomonas alcaliphila strain Q1-3 EU 144361.1 (gi/ 157649155); 100\% similarity) and Pseudomonas lubricans strain SF1 FJ600733.1 (gi/222431627); $100 \%$ similarity). Dendrogram is showing (Figure 2) the percentage similarity of the bacterial isolate with different species of Pseudomonas.

\section{Optimum growth conditions}

The most suitable temperature for arsenic-resistant bacterial isolate was found to be $30^{\circ} \mathrm{C}$. P. lubricans showed maximum growth at $\mathrm{pH}$ 7. The growth curve pattern was studied by growing the organism in the presence of different As (III) concentrations $\left(0,0.5,1,2,3 \mathrm{mg} \mathrm{m}^{-1}\right)$. The growth pattern of the $P$. lubricans was significantly different compared with control and the growth rate of $P$. lubricans was lower in the presence of 1,2 and $3 \mathrm{mg}$ arsenite $\mathrm{ml}^{-1}$. The growth pattern is shown in Figure 3 .

\section{Multiple metal resistances}

P. lubricans was found to be resistant to $A s(I I I)$ up to a concentration of $3 \mathrm{mg} \mathrm{ml}^{-1}$. P. lubricans was also checked for its resistance to other heavy metal, like, $\mathrm{Cd}, \mathrm{Cr}(\mathrm{VI})$, $\mathrm{Cu}, \mathrm{Hg}$ and Ni. P. lubricans was able to resist $\mathrm{Cd}^{2+}(100$ $\left.\mu \mathrm{g} \mathrm{ml}^{-1}\right), \mathrm{Cu}^{2+}\left(700 \mu \mathrm{g} \mathrm{ml}^{-1}\right), \mathrm{Cr}^{6+}\left(500 \mu \mathrm{g} \mathrm{ml}^{-1}\right), \mathrm{Hg}^{2+}(400$ $\left.\mu \mathrm{g} \mathrm{ml}^{-1}\right)$ and $\mathrm{Ni}^{2+}\left(300 \mu \mathrm{g} \mathrm{ml}^{-1}\right)$. 


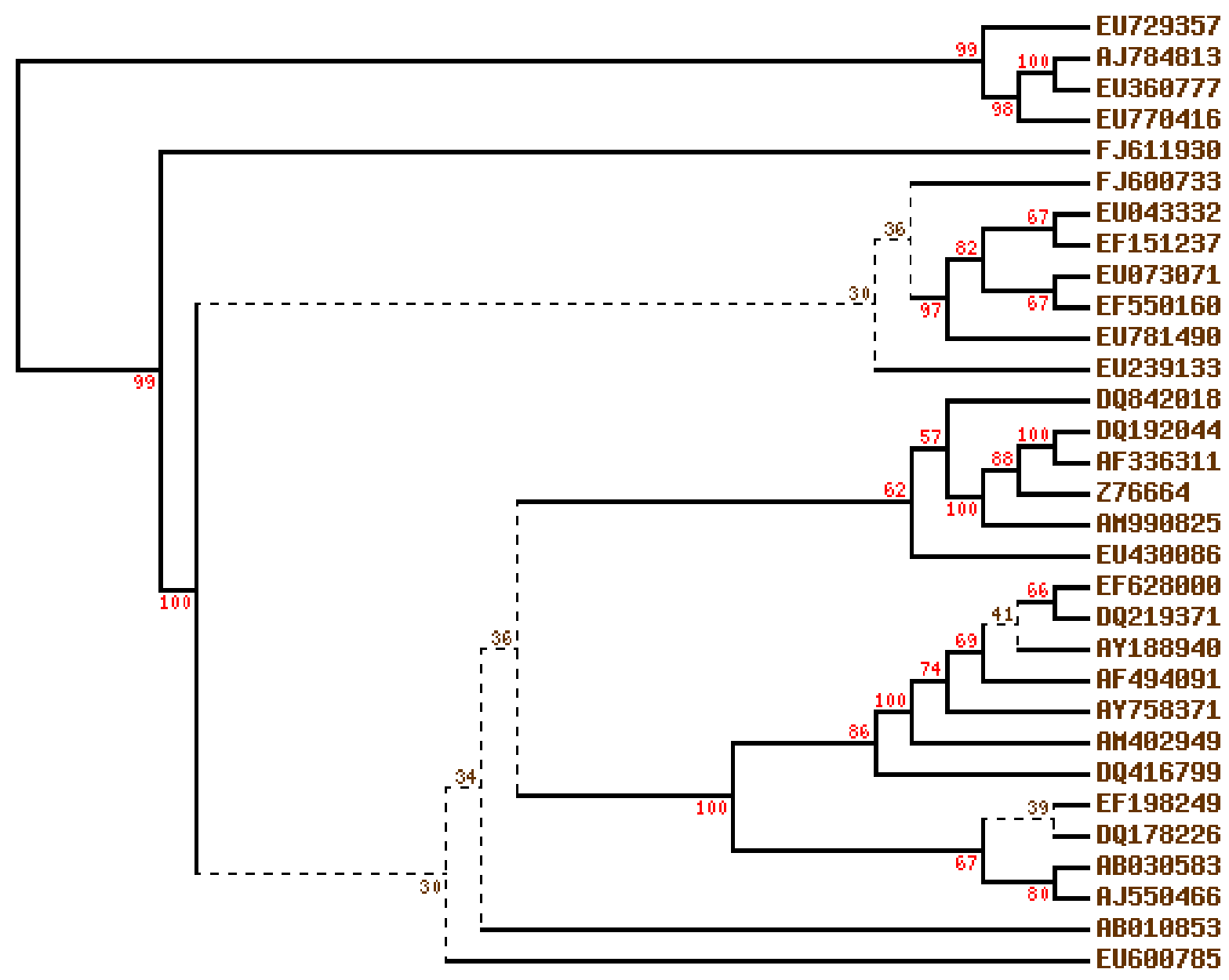

Figure 2. Dendrogram showing the similarity of $P$. lubricans with other close members of Pseudomonas sp.

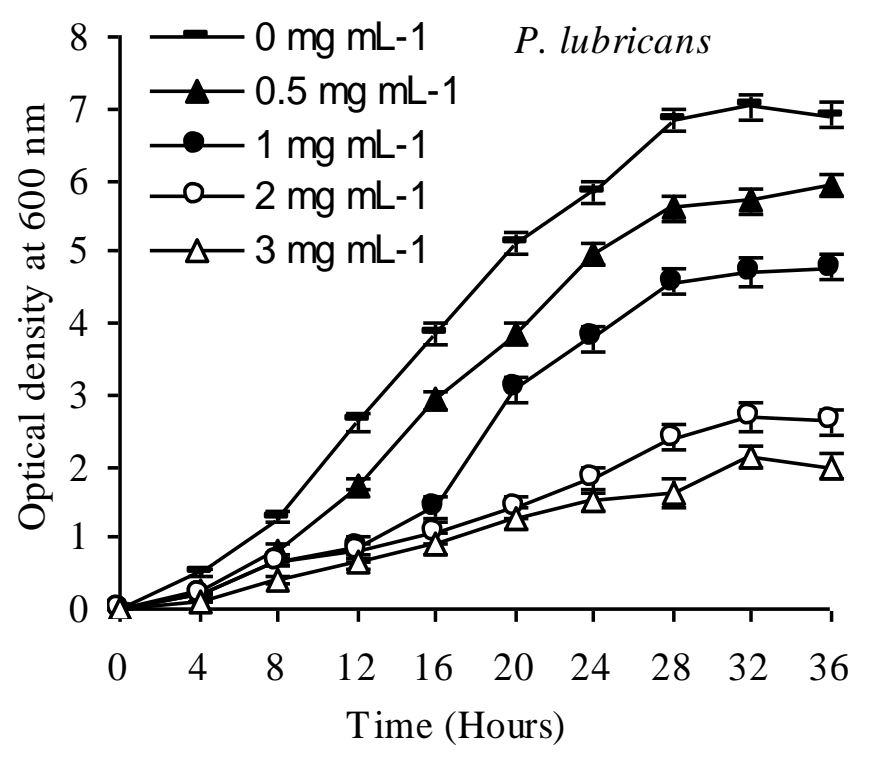

Figure 3. Effect of different arsenite concentrations $(0.5,1,2$ and $3 \mathrm{mg} \mathrm{l}^{-1}$ ) on the cell growth of $P$. lubricans in acetate minimal medium after incubation at $30^{\circ} \mathrm{C}$.

\section{Arsenite-oxidation ability of $P$. lubricans}

Arsenite oxidizing activity of the bacterial isolate was determined in crude extracts of bacterial cells. P. lubricans could oxidize $42 \% \mathrm{As}$ (III) (42 $\mathrm{gg} \mathrm{mg}^{-1}$ of protein), $78 \%\left(78 \mu \mathrm{g} \mathrm{mg}^{-1}\right.$ of protein) and $95 \%\left(95 \mu \mathrm{g} \mathrm{mg}^{-1}\right.$ of protein) from the medium after 24,48 and $72 \mathrm{~h}$, respectively. The arsenite oxidase activity was insignificant in culture without arsenite when compared with As(III)treated culture.

\section{DISCUSSION}

A variety of mechanisms exist for the removal of heavy metals from aqueous solution by bacteria, fungi, ciliates, algae, mosses, macrophytes and higher plants (Holan and Volesky, 1994; Pattanapipitpaisal et al., 2002; Rehman et al., 2007, 2008). The cellular response to the presence of metals includes various processes such as biosorption by cell biomass, active cell transport, binding by cytosolic molecules, entrapment into cellular capsules, 
Table 1. Arsenite resistance in different microorganisms.

\begin{tabular}{|l|c|l|}
\hline \multicolumn{1}{|c|}{ Microorganisms } & Arsenite (mM) & \multicolumn{1}{c|}{ Reference } \\
\hline Aeromonas sp. CA1, Exiguobacterium sp. WK6 & 20 & Anderson and Cook (2004) \\
Corynebacterium glutamicum & 60 & Mateos et al. (2006) \\
Aeromonas, Bacillus, Pseudomonas & 16.6 & Pepi et al. (2007) \\
Pseudomonas putida & 26 & Chang et al. (2007) \\
Thiomonas sp. & 2.6 & Duquesne et al. (2008) \\
Pseudomonas sp. & 0.5 & Valenzuela et al. (2009) \\
Pseudomonas lubricans & 40 & This study \\
\hline
\end{tabular}

precipitation and oxidation-reduction reactions (Gadd, 1990; Lovely and Coates, 1997) as well as protein-DNA adduct formation (Zhitkovitch and Costa, 1992) and induction of stress proteins (Ballatori, 1994).

The arsenic-resistant bacterium isolated in this study was, $P$. lubricans, based on 165 rDNA sequence analysis. The genus Pseudomonas is composed of ubiquitous bacteria endowed with a remarkable adaptability to diverse environments. Pseudomonas aeruginosa strains isolated from marine environments also showed arsenicresistance (de Vincente et al., 1990).

Arsenite resistant bacteria have also been isolated from industrial effluents by several groups (Anderson and Cook, 2004; Mateos et al., 2006; Chang et al., 2007; Duquesne et al., 2008; Valenzuela et al., 2009). In this study, $P$. lubricans was found to be highly resistant to arsenite at a concentration of $3 \mathrm{mg} \mathrm{ml}^{-1}$ (Table 1). $P$. lubricans also showed resistance against $\mathrm{Ni}^{2+}, \mathrm{Cu}^{2+}$, $\mathrm{Cd}^{2+}, \mathrm{Hg}^{2}$ and $\mathrm{Cr}^{6+}$ at a concentration of $300,700,100$, 400 and $500 \mathrm{\mu g} \mathrm{ml}^{-1}$, respectively. The order of resistance, in terms of metal concentration, was $\mathrm{Cu}^{2+}>\mathrm{Cr}^{6+}>$ $\mathrm{Hg}^{2+}>\mathrm{Ni}^{2+}>\mathrm{Cd}^{2+}$.

Toxic metals in the environment select and maintain microbes possessing genetic determinants which confer resistance to the toxic compounds. In addition to chromosomal genes that function for uptake of inorganic arsenic as alternative substrates to useful nutrients, many microbes possess genes specifically confer resistance to inorganic arsenic, arsenate (As-(V)) and arsenite (As(III)), as their natural primary substrates (Silver and Phung, 1996; Rosen, 1999). In bacteria, these resistance determinants are often found on plasmid, which has facilitated their study at the molecular level (Silver and Phung, 2005).

Resistance to arsenic species in both Gram-positive and negative bacteria results from energy-dependent efflux of either arsenate or arsenite from the cell mediated through the ars operon (Cervantes et al., 1994; Ji and Silver, 1992a). Oxidation of As-(III), which is done by a periplasmic enzyme arsenite oxidase, represents a potential detoxification process that allows microorganisms to tolerate higher levels of arsenite. In this respect, various bacterial strains capable of oxidizing As (III) to $\mathrm{As}(\mathrm{V})$ have been reported (Mukhopadhyay et al., 2002; Chang et al., 2007; Duquesne et al., 2008; Valenzuela et al., 2009). In this study, $P$. lubricans showed its ability to oxidize As(III) 42, 78 and 95\% from the medium after 24 , 48 and $72 \mathrm{~h}$, respectively. The arsenite oxidase activity was insignificant in non-As (III)-treated culture as compared to the As(III)-treated culture. Arsenite-oxidizing bacteria could play an important role in both arsenic oxidation and mobilization and could be efficiently used in bioremediation of arsenic-polluted waters (Valenzuela et al., 2009).

\section{Conclusion}

The presence of arsenic in water is frequently reported and arsenite is more mobile, highly soluble and more toxic than arsenate. The most appropriate way of toxic arsenite removal is to oxidize it into arsenate which is less soluble and much more easily removed. In this study, $P$. lubricans showed, high resistance against arsenic up to $3 \mathrm{mg} \mathrm{ml}^{-1}$. Also, resistance to $\mathrm{Cu}^{2+}\left(700 \mu \mathrm{g} \mathrm{ml}^{-1}\right), \mathrm{Hg}^{2+}$ $\left(400 \mu \mathrm{g} \mathrm{ml}^{-1}\right), \mathrm{Ni}^{2+}\left(400 \mu \mathrm{g} \mathrm{ml}^{-1}\right)$ and $\mathrm{Cr}^{6+}\left(500 \mu \mathrm{g} \mathrm{ml}^{-1}\right)$ was noted. P. lubricans could oxidize As(III) 42,78 and $95 \%$ from the medium after 24,48 and $72 \mathrm{~h}$, respectively. Therefore $P$. lubricans may be applicable for the treatment of industrial effluents contaminated with arsenic.

\section{REFERENCES}

Ahluwalia SS, Goyal D (2007). Microbial and plant derived biomass for removal of heavy metals from wastewater. Bioresour. Technol. 98: 2243-2257.

Ahmed A, Rehman A (2009). Isolation of $\mathrm{Cr}$ (VI) reducing bacteria from industrial effluents and their potential use in bioremediation of chromium containing wastewater. J. Environ. Sci. 21: 814-820.

Anderson CR, Cook GM (2004). Isolation and characterization of arsenate-reducing bacteria from arsenic contaminated sites in New Zealand. Curr. Microbiol. 48: 341-347.

Anderson GL, Williams J, Hille R (1992). The purification and characterization of arsenite oxidase from Alcaligenes faecalis, a molybdenum-containing hydroxylase. J. Biol. Chem. 267: 23674123682.

APHA (1989). Standard Methods for the Examination of Water and Wastewater. APHA, $18^{\text {th }}$ ed. Washington, DC.

Arriaza B (2005). Arseniasis as an environmental hypothetical explanation for the origin of the oldest artificial mummification practice in the world. Chungara, 37: 255-260.

Ballatori N (1994). Glutathione mercaptides as transport forms of metals. Adv. Pharmacol. 27: 271-298.

Cervantes C, Ji G, Ramirez JL, Silver S (1994). Resistance to arsenic compounds in microorganisms. FEMS Microbiol. Rev. 15: 355-367. 
Carozzi NB, Kramer VC, Warren GW, Evola S, Koziel MG (1991). Prediction of insecticidal activity of Bacillus thuringiensis strains by polymerase chain reaction product profiles. Appl. Environ. Microbiol.

57: 3057-306.

Chang J-S, Yoon I-H, Kim K-W (2007). Isolation and ars detoxification of arsenite-oxidizing bacteria from abandoned arsenic-contaminated mines. J. Microbiol. Biotechnol. 17: 812-821.

Chou WC, Hawkins AL, Barrett JF, Griffin CA, Dang CV (2001). Arsenic inhibition of telomerase transcription leads to genetic instability. J. Clin. Invest. 108: 1541-1547.

Duquesne K, Lieutaud A, Ratouchniak J, Muller D, Lett M-C, Bonnefoy V (2008). Arsenic oxidation by a chemoautotrophic moderately acidophilic Thiomonas sp.: from the strain isolation to the gene study. Environ. Microbiol. 10(1): 228-237.

De-Vicente A, Aviles M, Codina JC, Borrego JJ, Romero P (1990). Resistance to antibiotics and heavy metals of Pseudomonas aeruginosa isolated from natural waters. J. Appl. Bacteriol. 68: 625632.

Dopson M, Lindstrom EB, Hallberg KB (2001). Chromosomally encoded arsenical resistance of the moderately thermophilic acidophile Acidithiobacillus caldus. Extremophiles, 5: 247-255.

Gaballa A, Helmann JD (3003). Bacillus subtilis CPx-type ATPases: Characterization of $\mathrm{Cd}, \mathrm{Zn}, \mathrm{Co}$ and $\mathrm{Cu}$ efflux systems. Biometals, 16: 497-505.

Gadd GM (1990). Heavy metal accumulation by bacteria and other microorganisms. Experientia, 46: 834-840.

Holan ZR, Volesky B (1995). Accumulation of Cd, lead and nickel by fungal and wood biosorbents. Appl. Biochem. Biotechnol. 53: 133146.

Hughes MF (2002). Arsenic toxicity and potential mechanisms of action. Toxicol. Lett. 133: 1-16.

Ji G, Silver S (1992a). Regulation and expression of the arsenic resistance operon of Staphylococcus aureus plasmid p. 1258. J. Bacteriol. 174: 3684-3694.

Krumova K, Nikolovska M, Groudeva V (2008). Isolation and identification of arsenic-transforming bacteria from arsenic contaminated sites in Bulgaria. Biotechnol. Biotechnol. Equip. 22(2): 721-728.

Kuan WH, Hu CY, Chiang MC (2009). Treatment of As (V) and As (III) by electrocoagulation using $\mathrm{Al}$ and Fe electrode. Water Sci. Technol. 60(5): 1341-1346.

Lett M-C, Paknikar K, Lievremont D (2001). A simple and rapid method for arsenite and arsenate speciation. In: Ciminelli VST, Garcia O, (eds), Biohydrometametallurgy-fundamentals, technology and sustainable development. Part B. Elsevier Sci., New York.

Liu C-P, Luo C-L, Gao Y, Li F-B, Lin L-W, Wu C-A, Li X-D (2009). Arsenic contamination and potential health risk implications at an abandoned tungsten mine, southern China. Environ. Pollut. Doi: 10.1016/j.envpol.2009.09.029.

Lovely DR, Coates JD (1997). Bioremediation of metal contamination. Curr. Opin. Biotechnol. 8: 285-289.

Lowry OH, Rosebrough NJ, Farr AL, Randall RJ (1951). Protein measurement wih the Folin phenol reagent. J. Biol. Chem. 193: 265 275.

Mateos LM, Ordonez E, Letek M, Gil JA (2006). Corynebacterium glutamicum as a model bacterium for the bioremediation of arsenic. Int. Microbiol. 9: 207-215.

Matsui M, Nishigori C, Toyokuni S, Takada J, Akaboshi M, Ishikawa M, Imamura S, Miyachi Y (1999). The role of oxidative DNA damage in human arsenic carcinogenesis: detection of 8-hydroxy-2'deoxyguanosine in arsenic-related Bowen's disease. J. Invest. Dermatol. 113: 26-31.

Mouedhen G, Feki M, De Petris-Wery M, Ayedi HF (2009). Electrochemical removal of $\mathrm{Cr}(\mathrm{VI})$ from aqueous media using iron and aluminum as electrode materials: towards a better understanding of the involved phenomena. J. Hazard. Mater. 168(2-3): 983-991.

Mukhopadhyay R, Rosen BP, Phung LT, Silver S (2002). Microbial arsenic: from geocycles to genes and enzymes. FEMS Microbiol. Rev. 26: 311-325.

Nies DH (1992). Resistance to cadmium, cobalt, zinc and nickel in microbes. Plasmid, 27: 17-28.
Niggemyer A, Spring S, Stackebrandt E, Rosenzweig RF (2001). Isolation and characterization of a novel $A s(V)$-reducing bacterium: implications for arsenic mobilization and the genus Desulfitobacterium. Appl. Environ. Microbiol. 67: 5568-5580.

Nourbakhsh M, Sag Y, Ozer D, Aksu Z, Kutsal T, Calgar A (1994). A comparative study of various biosorbents for removal of chromium $(\varepsilon)$ ions from industrial wastewater. Process Biochem. 29: 1-5.

Pattanapipitpaisal P, Mabbett AN, Finlay JA, Beswick AJ, PatersonBeedle M, Essa A, Wright J, Tolley MR, Badar U, Ahmed N, Hobman JL, Brown NL, Macaskie LE (2002). Reduction of Cr (VI) and bioaccumulation of chromium by Gram-positive and Gram-negative microorganisms not previously exposed to Cr-stress. Environ. Technol. 23: 731-745.

Pattanapipitpaisal P, Brown NL, Macaskie LE (2001). Chromate reduction and 16S rRNA identification of bacteria isolated from a $\mathrm{Cr}$ (VI)-contaminated site. Appl. Microbiol. Biotechnol. 57: 257-261.

Pepi M, Volterrani M, Renzi M, Marvasi M, Gasperini S, Franchi E, Focardi SE (2007). Arsenic-resistant bacteria isolated from contaminated sediments of the Orbetello Lagoon, Italy and their characterization. J. Appl. Microbiol. 103: 2299-2308.

Rehman A, Ali A, Muneer B, Shakoori AR (2007). Resistance and biosorption of mercury by bacteria isolated from industrial effluents. Pak. J. Zool. 39(3): 137-146.

Rehman A, Shakoori FR, Shakoori AR (2007). Heavy metal resistant Distigma proteus (Euglenophyta) isolated from industrial effluents and its possible role in bioremediation of contaminated wastewaters. World J. Microbiol. Biotechnol. 23: 753-758.

Rehman A, Shakoori FR, Shakoori AR (2008). Heavy metal resistant freshwater ciliate, Euplotes mutabilis, isolated from industrial effluents has potential to decontaminate wastewater of toxic metals. Bioresour. Technol. 99: 3890-3895.

Rosen BP (1999). Families of arsenic transporters. Trends Microbiol. 7: 207-212.

Silver S, Phung LT (1996). Bacterial heavy metal resistance: new surprises. Ann. Rev. Microbiol. 50: 753-789.

Silver S, Phung LT (2005). Genes and enzymes involved in bacterial oxidation and reduction of inorganic arsenic. Appl. Environ. Microbiol. 71: 599-608.

Simeonova D, Lievremont D, Lagarde F, Muller D, Groudeva V, Lett MC (2004). Microplate screening assay for detection of arseniteoxidizing and arsenate-reducing bacteria. FEMS Microbiol. Lett. 237: 249-253.

Smith AH, Lopipero PA, Bates MN, Steinmaus CM (2002). Public health. Arsenic epidemiology and drinking water standards. Science, 296: 2145-2146.

Shi H, Shi X, Liu K-J (2004). Oxidative mechanisms of arsenic toxicity and carcinogenesis. Mol. Cell. Biochem. 255: 67-78.

Suresh K, Reddy GSN, Sengupta S, Shivaji S (2004). Deinococcus indicus sp. nov., an arsenic-resistant bacterium from an aquifer in West Bengal, India. Int. J. Syst. Evol. Microbiol. 54: 457-461.

Wang TS, Hsu TY, Chung CH, Wang AS, Bau DT, Jan KY (2001). Arsenite induces oxidative DNA adducts and DNA-protein cross-links in mammalian cells. Free Radical Biol. Med. 31: 321-330.

White C, Gadd G (1986). Uptake and cellular distribution of copper, cobalt and cadmium in strains of Saccharomyces cerevisiae cultured on elevated concentration of these metals. FEMS Microbiol. Rev. 38 227-283.

Wu W, Graves LM, Jaspers I, Devlin RB, Reed W, Samet JM (1999). Activation of the EGF receptor signaling pathway in human airway epithelial cells exposed to metals. Am. J. Physiol. 277: 924-931.

Valenzuela C, Campos VL, Yanez J, Zaror CA, Mondaca MA (2009). Isolation of arsenite-oxidizing bacteria from arsenic-enriched sediments from Camarones River, Northern Chile. Bull. Environ. Contam. Toxicol. 82: 593-596.

Zhitkovitch A, Costa M (1992). A simple sensitivity assay to detect DNAprotein crosslinks in intact cells and in vivo. Carcinogenesis, 13: 1485-1489. 